\title{
Variation in Antioxidant Responses in Rice (Oryza sativa L.) Genotypes Differing in Sensitivity to Heat Stress
}

\author{
K.P. Sharma ${ }^{1 *}$, N. Sharma ${ }^{2}$ and R. Kaur ${ }^{2}$ \\ ${ }^{1}$ Department of Biochemistry, Punjab Agricultural University, Ludhiana, \\ Punjab, India 141004 \\ ${ }^{2}$ Department of Plant Breeding and Genetics, Punjab Agricultural University, \\ Ludhiana, Punjab, India 141004 \\ *Corresponding author
}

\begin{abstract}
A B S T R A C T
Keywords

Rice, Date of transplanting, Heat stress, Enzymatic antioxidants, Nonenzymatic antioxidants

Article Info

Accepted:

12 June 2019

Available Online:

10 July 2019

A field experiment was conducted to study the response of antioxidant enzymes to oxidative damage caused by heat stress induced by changing dates of transplanting in two rice (Oryza sativa L.) genotypes viz., 'N22' (heat tolerant) and 'IR8' (heat susceptible). During grain filling period, constitutive level of antioxidative enzymes viz., superoxide dismutase, catalase, ascorbate peroxidase, was found to be $35.7,88.8$ and $84.1 \%$ higher respectively, while the content of non-enzymatic antioxidants viz., ascorbate and proline was 78.5 and $81.8 \%$ higher respectively, in ' $\mathrm{N} 22$ ' than in 'IR8' under heat stress encountered during early transplanting. In contrast, the hydrogen peroxide and malondialdehyde content were 42.1 and $28.4 \%$ higher in 'IR8' during early transplanting. Heat stress resulted in significant reduction of chlorophyll content during early transplanting in both the genotypes though the reduction was less in ' $\mathrm{N} 22$ ' $(27.6 \%)$ as compared to 'IR8' (45.2\%). The increased and timely response of antioxidant enzymes along with the non enzymatic antioxidants is suggestive of their significant role in development of tolerance exhibited by the cultivar 'N22' under heat stress conditions.
\end{abstract}

\section{Introduction}

Heat stress is one of the major factors affecting rice (Oryza sativa L.) productivity in many areas and it occurs more frequently and severely because of the global warming. Global climatic predictions indicate increased frequency of heat spikes and warmer nights which exert additional challenges to achieve higher crop yields (IPCC, 2013). Taking global harvested area in consideration, climate model predicts that $16 \%$ of the rice growing area would be exposed to at least $5^{\circ} \mathrm{C}$ of temperature above the critical threshold during the reproductive period, by 2030, with a constant increase to $27 \%$ of rice growing area by 2050 (Gourdji et al., 2013). High temperature stress during grain filling can diminish seed set by accelerating senescence thereby reducing crop yields ((Wahid et al., 
2007; Hasanuzzaman et al., 2013; Zafar et al., 2017 and Siddique et al., 1999).

Under prolonged stress exposure, photosynthetic activity is further inhibited by excessive accumulation of reactive oxygen species (ROS), causing damage to the membranes, proteins and chlorophyll molecules of the photosynthetic apparatus (Allakhverdiev et al., 2008; Silva et al2010; Redondo-Gómez, 2013; Awasthi et al., 2014; Das et al., 2016; Tricker et al., 2018). Reactive oxygen species (ROS) such as singlet oxygen $\left({ }^{1} \mathrm{O}_{2}\right)$, superoxide $\left(\mathrm{O}_{2}{ }^{-{ }^{-}}\right)$, hydrogen peroxide $\left(\mathrm{H}_{2} \mathrm{O}_{2}\right)$ and hydroxyl radicals $\left(\mathrm{OH}^{*}\right)$ produced during aerobic metabolism in the intracellular organelles of plant cells are readily scavenged by plant antioxidant defense systems which are chiefly antioxidant enzymes and non-enzymatic antioxidants. Plants use a complex antioxidants system to regulate ROS levels and avoid toxicity, but changes in redox status are also perceived by plants as a signature of a specific stress that will result in a corresponding acclimation response (Foyer and Noctor, 2005; Choudhury et al., 2017). Various environmental stresses such as high temperature, salt stress, drought stress, disrupt photosystem energy balance, functions of plasma membrane enzymes and glyoxisomal photorespiration, which disturb biochemical reactions in chloroplasts and mitochondria. These changes result in accumulation of ROS beyond the antioxidant capacity of plants (Karuppanapandian et al., 2013). Genotypes vary in their response to various stresses because of variation in their antioxidant systems.

Rice is tolerant to high temperature, but excessively high temperature impairs its growth and reproduction, especially impacts on the upper three functional leaves, which are the main photosynthetic organs during the later growth period and are important for grain filling. Significant variation exists among rice germplasm in response to temperature stress. Booting and flowering stages are the most sensitive to high temperature, and may sometimes lead to complete sterility (Shah et al., 2011). Heat stress at this time could cause a serious reduction in grain yield due to pollen sterility, empty or unfilled grains, low grain weight and poor seed setting (Tao et al., 2007). High temperature during grain filling stage of rice can decrease starch content, grain plumpness and protein accumulation, affecting both quality and yield of rice ( $\mathrm{Li}$ et al., 2002). Therefore, the present investigation was carried out to study the oxidative status of rice genotypes during their reproductive phase of growth when transplanted at different times.

\section{Materials and Methods}

\section{Plant material and Experimental conditions}

Two rice genotypes viz. heat tolerant 'N22' and heat susceptible 'IR8' were employed in this study. The rice genotypes were sown during the second week of March (early) and in the third week of May (normal) to expose the crops to different temperature regimes. The seedlings of rice cultivars were raised in the wooden trays $(50 \times 40 \times 10 \mathrm{~cm})$ in the glasshouse. Thirty- day old seedlings were transplanted in the field in complete randomized block design with three replications.

The recommended agronomic practices were followed. The temperatures under the two sowings were recorded by the field meterological laboratory and then the activities of the enzymes were studied in the flag leaf during anthesis and dough stage of grain development. All enzymatic and other estimations like malondialdehyde, ascorbate, chlorophyll and proline content were estimated in the mid- region of the flag leaf. 
Extraction and estimation of antioxidant enzymes

For enzyme extracts and assays, leaf tissue from each treatment was homogenized in icecold $50 \mathrm{mM}$ potassium phosphate buffer $(\mathrm{pH}$ 7.0) containing $0.1 \mathrm{mM}$ ethylene diamine tetraacetic acid (EDTA) and 1\% polyvinyl pyrrolidone (PVP). The homogenate was centrifuged at $10,000 \times \mathrm{g}$ for $20 \mathrm{~min}$ at $4^{\circ} \mathrm{C}$, and the supernatant was used for activity measurement.

Superoxide dismutase (SOD, EC 1.15.1.1) activity was measured by monitoring its ability to inhibit the auto-oxidation of pyrogallol. The assay was carried out in 100 $\mathrm{mM}$ Tris $\mathrm{HCl}$ buffer ( $\mathrm{pH}$ 8.2), $3 \mu \mathrm{M}$ EDTA, 6 $\mu \mathrm{M}$ pyrogallol solution to which enzyme extract was added. The change in absorbance was recorded for 3 minutes at $420 \mathrm{~nm}$ at regular intervals (Marklund and Marklund, 1974). One unit of SOD activity has been defined as the amount of enzyme required to cause 50\% inhibition of auto-oxidation of pyrogallol under the experimental conditions. The specific activity of SOD is expressed as units $\mathrm{mg}^{-1}$ protein.

Peroxidase (POX, EC 1.11.1.7) activity was determined by following the appearance of brown colouration resulting from guaiacol oxidation to tetraguaiacol in the presence of $\mathrm{H}_{2} \mathrm{O}_{2}$. To $150 \mu \mathrm{M}$ guaiacol prepared in 100 $\mathrm{mM}$ potassium phosphate buffer ( $\mathrm{pH}$ 6.5), To $0.1 \mathrm{ml}$ of enzyme extract, $0.08 \mathrm{mM} \mathrm{H}_{2} \mathrm{O}_{2}$ was added and the change in absorbance was recorded at $470 \mathrm{~nm}$ (Shannon et al., 1966). The unit of enzyme activity has been defined as the change in absorbance at $470 \mathrm{~nm} \mathrm{~min}{ }^{-1}$ $\mathrm{g}^{-1}$ fresh weight and $\mathrm{min}^{-1} \mathrm{mg}^{-1}$ protein.

Glutathione reductase (GR, EC 1.6.4.2) was estimated by the method of Esterbauer and Grill (1978). The reaction was started by adding $0.2 \mathrm{M}$ potassium phosphate buffer $(\mathrm{pH}$
7.5), $0.04 \mu \mathrm{M}$ EDTA, $0.3 \mu \mathrm{M} \mathrm{MgCl}_{2}, 0.001$ $\mu \mathrm{M}$ of NADPH and $0.8 \mathrm{ml}$ of enzyme extract followed by $0.1 \mu \mathrm{M}$ of oxidized glutathione. The enzyme activity was estimated as decrease of absorbance at $340 \mathrm{~nm}$ after an interval of 30 seconds upto 3 minutes. The molar extinction coefficient for NADPH is $6.22 \mathrm{mM}^{-1} \mathrm{~cm}^{-1}$. The specific activity of GR was expressed as nmoles of $\mathrm{NADP}^{+}$formed $\mathrm{min}^{-1} \mathrm{mg}^{-1}$ protein.

Catalase (CAT, EC 1.11.1.6) activity was assayed following Chance and Maehly (1955). The assay was carried out in $50 \mathrm{mM}$ sodium phosphate buffer $(\mathrm{pH} 7.5)$ to which $0.1 \mathrm{ml}$ of enzyme extract and $0.039 \mathrm{mM} \mathrm{H}_{2} \mathrm{O}_{2}$ was added. The utilization of $\mathrm{H}_{2} \mathrm{O}_{2}$ was recorded for 3 minutes by measuring the decrease in absorbance at $240 \mathrm{~nm}$. Extinction coefficient for hydrogen peroxide has the value of $0.0394 \mathrm{mM}^{-1} \mathrm{~cm}^{-1}$. CAT activity was expressed as $\mu$ moles of $\mathrm{H}_{2} \mathrm{O}_{2}$ decomposed $\min ^{-1} \mathrm{mg}^{-1}$ protein.

Ascorbate peroxidase (APX, EC 1.11.1.11) activity was measured according to the method of Nakano and Asada (1987) by estimating the rate of ascorbate oxidation. The reaction mixture consisted of $50 \mathrm{mM}$ sodium phosphate buffer ( $\mathrm{pH} 7.5), 0.4 \mu \mathrm{M}$ ascorbic acid, $0.2 \mathrm{ml}$ of enzyme extract and $0.039 \mathrm{mM}$ $\mathrm{H}_{2} \mathrm{O}_{2}$ solution. Decrease in absorbance was measured at $290 \mathrm{~nm}$ for 3 minutes at an interval of 30 seconds $\left(\varepsilon=2.8 \mathrm{mM}^{-1} \mathrm{~cm}^{-1}\right)$. APX was expressed as nmoles of monodehydroascorbate formed $\mathrm{min}^{-1} \mathrm{mg}^{-1}$ protein. The protein amount was determined by the Lowry method (1951) using bovine serum albumin (BSA) as a standard.

Estimation of hydrogen peroxide, ascorbic acid, malondialdehyde and proline content

Hydrogen peroxide $\left(\mathrm{H}_{2} \mathrm{O}_{2}\right)$ content was measured according to Sinha (1971). Leaf tissue was homogenized with $10 \mathrm{mM}$ 
potassium phosphate buffer $(\mathrm{pH}$ 7.0). The homogenate was centrifuged at $10,000 \mathrm{x} \mathrm{g}$ for 20 minutes. An aliquot of $2 \mathrm{ml}$ was mixed with equal volume of $5 \%$ potassium dichromate and glacial acetic acid (1:3 v/v) and the absorbance was read at $570 \mathrm{~nm}$ against the reagent blank. $\mathrm{H}_{2} \mathrm{O}_{2}$ content was calculated from the standard curve prepared using $\mathrm{H}_{2} \mathrm{O}_{2}$ concentrations ranging from 20 to $100 \mu$ moles. The $\mathrm{H}_{2} \mathrm{O}_{2}$ content was expressed as mmoles $\mathrm{g}^{-1} \mathrm{FW}$.

Ascorbic acid (Asc) content was evaluated according to method of Law et al., (1983). The leaf tissue was extracted with $5 \%$ ice cold metaphosphoric acid. An aliquot measuring $0.4 \mathrm{ml}$ was added to reaction mixture containing $0.002 \mathrm{mM}$ EDTA, $1.7 \%$ TCA, $0.013 \mathrm{mM} \mathrm{FeCl} \mathrm{m}_{3}$ prepared in $0.1 \mathrm{M}$ potassium phosphate buffer ( $\mathrm{pH} 7.5$ ), 7.6\% o-phosphoric acid and $0.035 \mathrm{mM}$ bipyridyl. After an incubation of $40 \mathrm{~min}$ at $40^{\circ} \mathrm{C}$ the absorbance was measured at $525 \mathrm{~nm}$. A standard curve in the range of 10-40 nmoles of ascorbic acid was used for determination of ascorbic acid content. Asc concentration was expressed as nmoles $\mathrm{g}^{-1} \mathrm{FW}$.

For the extraction of malondialdehyde (MDA) assay, leaf tissue was homogenized with 5\% trichloroacetic acid (TCA) and centrifuged at $10,000 \mathrm{x} \mathrm{g}$ for 15 minutes at $25^{\circ} \mathrm{C}$. Supernatant was taken for estimation of MDA (Ohkhawa et al., 1979). The supernatant was mixed with an equal volume of $20 \%(\mathrm{w} / \mathrm{v})$ TCA containing $0.5 \%$ thiobarbituric acid (TBA). The mixture was heated to $96^{\circ} \mathrm{C}$ for 30 minutes and immediately cooled in ice and centrifuged at $10,000 \times \mathrm{g}$ for 10 minutes at $4^{\circ} \mathrm{C}$. The absorbance was recorded at $532 \mathrm{~nm}$. Correction for non- specific absorbance was made by subtracting the absorbance value taken at $600 \mathrm{~nm}$. The results were calculated by using extinction coefficient of $155 \mathrm{mM}^{-1}$ $\mathrm{cm}^{-1}$ and expressed as nmoles $\mathrm{g}^{-1} \mathrm{FW}$.
The powdered dried tissue was extracted with $3 \%$ aqueous sulfosalicylic acid (w/v) and the extract was filtered through Whatman filter paper no.1. The filterate was used for proline (Pro) estimation (Bates et al., 1973). An aliquot of $2 \mathrm{ml}$ was mixed with $2 \mathrm{ml}$ of acid ninhydrin solution and $2 \mathrm{ml}$ of glacial acetic acid.

The reaction mixture was incubated in boiling water for 1 hour. The reaction was terminated by immersing the tubes in ice-cold water for 5 min. The reaction mixture was extracted with $4 \mathrm{ml}$ toluene, mixed vigorously and absorbance of the chromophore containing upper toluene layer was read at $520 \mathrm{~nm}$ using toluene as blank. The concentration of proline was calculated from standard curve containing 0.02 to $0.2 \mu$ moles of proline run simultaneously.

Chlorophyll content was estimated by following the method of Anderson and Boardman (1964). The leaf tissue was homogenized with $80 \%$ ice cold acetone and centrifuged at $5,000 \mathrm{x}$ g for 5 minutes at $4{ }^{\circ} \mathrm{C}$.

The residue was recentrifuged with $80 \%$ acetone at $5,000 \mathrm{x} \mathrm{g}$ for 5 minutes. This process was repeated twice to completely extract chlorophyll. Supernatants were pooled and the absorbance of the supernatant was recorded at $645 \mathrm{~nm}$ and $663 \mathrm{~nm}$. The chlorophyll content was expressed as $\mathrm{mg} \mathrm{g}^{-1}$ FW.

\section{Statistical analysis}

Data were reported as mean \pm standard deviation for triplicates determinations of each sample. Analysis of variance and Tukey Test were performed using SPSS 16.0 (SPSS Inc., Chicago, IL, USA) to identify differences between values. Statistical significance was defined at level of $\leq 0.05 \%$ unless specified otherwise. 


\section{Results and Discussion}

During our study, the mean maximum temperature encountered during anthesis by 'N22' and 'IR8' was $3.7^{\circ} \mathrm{C}$ and $3.6^{\circ} \mathrm{C}$ higher respectively in early transplanting (ET) compared to normal transplanting (NT). During dough stage, the temperature rise observed was $4.4^{\circ} \mathrm{C}$ and $4^{\circ} \mathrm{C}$ in ' $\mathrm{N} 22$ ' and 'IR8' respectively at ET compared to NT.

The maximum temperature recorded during anthesis stage was $26.4^{\circ} \mathrm{C}$ and $32^{\circ} \mathrm{C}$, during NT while it was observed to be $33.6^{\circ} \mathrm{C}$ and $36^{\circ} \mathrm{C}$ during ET for, N22 and IR8 respectively. The minimum temperature was $25.6^{\circ} \mathrm{C}$ and $25.3^{\circ} \mathrm{C}$ during NT, while during ET, it was $25.8^{\circ} \mathrm{C}$ and $28.4^{\circ} \mathrm{C}$ for $\mathrm{N} 22$ and IR8 respectively. The mean temperature was $26^{\circ} \mathrm{C}$ and $28.65^{\circ} \mathrm{C}$ and $29.7^{\circ} \mathrm{C}$ and $32.2^{\circ} \mathrm{C}$ for N22 and IR8, during NT and ET, respectively. The maximum temperature during dough stage was observed to be $31.2^{\circ} \mathrm{C}$ and $27.8^{\circ} \mathrm{C}$ during NT and $37^{\circ} \mathrm{C}$ and $32.2^{\circ} \mathrm{C}$ during ET, for $\mathrm{N} 22$ and IR8 respectively. The minimum temperature was $26.4^{\circ} \mathrm{C}$ and $23.4^{\circ} \mathrm{C}$ during NT, and $28.4^{\circ} \mathrm{C}$ and $27^{\circ} \mathrm{C}$ during ET respectively. The mean temperature was $28.3^{\circ} \mathrm{C}$ and $25.6^{\circ} \mathrm{C}$ during NT, and $32.7^{\circ} \mathrm{C}$ and $29.6^{\circ} \mathrm{C}$ during ET, for $\mathrm{N} 22$ and IR8 respectively.

Under NT conditions, oxidative damage to cellular constituents is limited because of efficient scavenging of ROS by rapidly responsive antioxidant system composed of antioxidant enzymes and redox metabolites. However, under ET, when the crop is exposed to high temperature during grain filling stage, cellular damage may occur due to an imbalance in the formation and scavenging of ROS. The present study has shown that there were significant changes in the activity of the antioxidant enzymes viz., SOD, GR, POX, CAT and APX in response to early transplanting. The co-ordinated function of following antioxidant enzymes help in the processing of ROS and regeneration of reduced ascorbate and glutathione metabolites.

\section{Effect of high temperature on antioxidant enzyme activities}

SOD has been proposed to provide the first line of defence against ROS by catalyzing the dismutation of $\mathrm{O}_{2}{ }^{--}$to $\mathrm{H}_{2} \mathrm{O}_{2}$ and $\mathrm{O}_{2}$. In our study, both cultivars showed higher SOD activity when the crop encountered heat stress during grain development period (Fig. 1a). The highest SOD activity was found in 'N22' at the anthesis stage (18.21 units $\mathrm{mg}^{-1}$ protein) during ET followed by the dough stage while the lowest activity (1.66 units $\mathrm{mg}^{-1}$ protein) was found at anthesis in 'IR8' during normal transplanting (NT). The overall mean activity irrespective of the grain filling stage, was 1.6 fold higher in 'N22' compared to 'IR8' ( $\mathrm{p}<$ 0.01 level). The upregulation of SOD is implicated in combating oxidative stress caused due to biotic and abiotic stress and has a critical role in the survival of plants under heat stress (Gur et al., 2010). The genotype 'N22' exhibited significantly higher constitutive and induced SOD activity compared to 'IR8' during both anthesis and dough stage, indicating that it has better scavenging capacity and higher tolerance to heat stress than 'IR8'.

A much lower activity was observed during NT compared to ET in both the genotypes. During NT, CAT activity was higher in 'IR8' compared to 'N22' while the reverse was true during ET at both anthesis and dough stages. The mean CAT activity was found to be 8.9 fold higher during ET in 'N22' compared to 'IR8' (Fig. 1b). CATs have the potential to directly dismutate $\mathrm{H}_{2} \mathrm{O}_{2}$ into $\mathrm{H}_{2} \mathrm{O}$ and $\mathrm{O}_{2}$ and is indispensable for the detoxification of ROS during stress generated in peroxisomes by oxidases involved in B-oxidation of fatty 
acids, photorespiration and purine catabolism (Gill and Tuteja, 2010). CAT activity in our study was found to increase significantly ( $\mathrm{p}<$ 0.01 level) in both the cultivars, at ET as compared to NT but this increase was 104 fold and 4.2- fold in 'N22' and 'IR8', respectively. This shows an enhanced ability of 'N22' to tolerate high temperature.

Significant increase in APX activity was observed during ET at both anthesis and dough stages in 'N22' compared to NT ( $p<$ 0.01 level) (Fig. 1c). In contrast, the APX activity in 'IR8' was not significantly affected at the two transplanting dates at both anthesis and dough stages during grain filling. The highest APX activity was observed in 'N22' during ET at the dough stage (64.73 nmoles of monohydroascorbic acid formed $\mathrm{min}^{-1} \mathrm{mg}^{-1}$ protein) while the lowest activity was also observed in 'IR8' at anthesis stage (6.62 nmoles of monohydroascorbic acid formed $\mathrm{min}^{-1} \mathrm{mg}^{-1}$ protein). APX is thought to play the most essential role in scavenging ROS and protecting cells in higher plants. APX is involved in scavenging of $\mathrm{H}_{2} \mathrm{O}_{2}$ in waterwater and ASH-GSH cycles and utilizes ascorbate (ASH) as the electron donor. APX has a higher affinity for $\mathrm{H}_{2} \mathrm{O}_{2}(\mu \mathrm{M}$ range) than CAT and PO (mM range) and it may have a more crucial role in the management of ROS during abiotic stress (Gill and Tuteja, 2010). In the present study, higher induction of APX was observed at ET as compared to NT in 'N22' and may be a contributing factor in conferring tolerance to heat stress.

A low GR activity was observed in our study but followed the same pattern as that of other ROS scavenging enzymes (Fig. 1d). Higher GR activity was observed during ET in both genotypes with the highest being observed in 'N22' at anthesis (7.06 nmoles NADP $^{+}$ formed $\mathrm{min}^{-1} \mathrm{~g}^{-1}$ fresh weight) and the lowest in dough stage of 'IR8' $\left(0.61\right.$ nmoles NADP ${ }^{+}$ formed $\mathrm{min}^{-1} \mathrm{~g}^{-1}$ fresh weight) (Fig. 1d) ( $\mathrm{p}<$ 0.01 level). GR activity was reported to increase during the presence of $\mathrm{Cd}$ during drought stress in O. sativa seedlings (Sharma and Dubey, 2005).

POXs are known as stress ameliorating enzymes that actively respond to damages in plant metabolism and act as early and sensitive indicators of heat stress. As compared to other antioxidant enzymes, a low activity of peroxidase (POX) in both the genotypes was recorded. However, at ET compared to NT; it was significantly higher i.e; 3 and 8 folds in 'N22' and 'IR8' respectively $(\mathrm{p}<0.01$ level). The heat tolerant genotype 'N22' possessed a higher constitutive level of POX compared to the heat susceptible 'IR8' genotype at both transplanting dates. The POX activity was higher at the anthesis stage in both 'N22' and 'IR8' compared to the dough stage during both transplanting dates except 'N22' during NT when it exhibited similar activity at both anthesis and dough stage. Increase in the activity of POX in response to heat stress in cotton (Gossypium hirsutum L.) has been reported (Gur et al., 2010) where the POX activity increased as a response to increase in temperatures to $38^{\circ} \mathrm{C}$ and $45^{\circ} \mathrm{C}$. Similarly, though the contribution of POX towards manipulating the redox status in ' $N 22$ ' and 'IR8' was very less in our study, it was appreciably higher during ET in 'N22' compared to 'IR8'. During NT, almost negligible POX activity was detected in both cultivars.

It is clear from our data that there was a significant increase in the activity of the antioxidant enzymes viz., SOD, CAT and APX in response to ET in both the genotypes except during anthesis in IR, APX activity was lower than NT. This increase was significantly higher in 'N22' compared to 'IR8' and may contribute towards the tolerance exhibited by it to high temperature encountered during ET (Fig. 1a-c). 


\section{Non enzymatic antioxidants}

Hydrogen peroxide $\left(\mathrm{H}_{2} \mathrm{O}_{2}\right)$ regulates the expression of various genes, including those encoding antioxidative enzymes (Geisler et al., 2006). It is the most stable of the ROS and therefore plays a crucial role as a signalling molecule in various physiological processes. $\mathrm{H}_{2} \mathrm{O}_{2}$ acts as a second messenger for signals generated by means of ROS because of its relatively long life and high permeability across membranes (Quan et al., 2002). $\mathrm{H}_{2} \mathrm{O}_{2}$ content was found to be significantly higher during ET compared to NT in both the genotypes (Fig. 1e). However, there was a more drastic increase in 'IR8' (12.24 fold) as compared to 'N22' (1.36 fold) during ET. $\mathrm{H}_{2} \mathrm{O}_{2}$ content was higher in the dough stage in both the genotypes at both transplanting dates. The highest content was present at the dough stage of 'IR8' (264.33 mmoles $\mathrm{g}^{-1} \mathrm{FW}$ ) at ET. It was interesting to note that during NT, 'N22' possessed 5.19 fold higher $\mathrm{H}_{2} \mathrm{O}_{2}$ content as compared to 'IR8' while during ET, 'IR8' possessed 1.73 times higher $\mathrm{H}_{2} \mathrm{O}_{2}$ content ( $\mathrm{p}<0.01$ level). Higher SOD activity results in higher production of $\mathrm{H}_{2} \mathrm{O}_{2}$. In 'IR8', the higher $\mathrm{H}_{2} \mathrm{O}_{2}$ content during ET could be a consequence of low APX and CAT activity. Suriyasak et al., (2017) reported $\mathrm{H}_{2} \mathrm{O}_{2}$ content to be significantly higher under heat stress $\left(30^{\circ} \mathrm{C}\right)$ than under control $\left(25^{\circ} \mathrm{C}\right)$ conditions.

Ascorbate (Asc) content decreased with ET in both the genotypes though the decrease was much higher than NT for 'IR8' (10.9 fold) as compared to 'N22' (1.8 fold) ( $\mathrm{p}<0.01$ level). One of the reason for 'N22' being thermotolerant may be the presence of higher Asc content even at high temperature which helps to prevent or minimize the damaged caused by ROS. Ascorbic acid (ASH) is one of the most abundant, powerful and water soluble antioxidant which acts to prevent or minimize the damage caused by ROS in plants. It occurs in all plant tissues, usually being higher in photosynthetic cells and meristems (and some fruits). Higher ascorbate content along with APX activity in 'N22' demonstrates its superior tolerance mechanism in terms of $\mathrm{H}_{2} \mathrm{O}_{2}$ scavenging over 'IR8' (Fig. 1f). Yang et al., (2008) have reported the importance of ascorbate in the amelioration of oxidative stress under abiotic stress in Picea asperata.

Malondialdehyde (MDA) content was significantly higher during ET in both the genotypes compared to NT (Fig. 2a). Maximum content was present in 'IR8' (49.10 $\mu$ moles $\mathrm{FW}$ ) during ET at the dough stage while the minimum content was recorded in 'N22' at the anthesis stage $\left(9.74 \mu\right.$ moles $\mathrm{g}^{-1}$ FW) ( $<$ < 0.01 level). MDA, a decomposition product of polyunsaturated fatty acid hydroperoxides, has been utilized as a suitable biomarker for the evaluation of lipid peroxidation or damage to plasmalemma and organelle membranes that increases with environmental stress. Lipid peroxidation is linked to the activity of antioxidant enzymes since with the increase of SOD, APX, GPX, CAT, etc oxidative stress tolerance is enhanced while MDA is decreased. Wang et al., (2011) reported that high temperature results in increase content of MDA, free proline and soluble sugars in the function leaves, while the chlorophyll content and photosynthetic rate of leaves was decreased. We observed that heat stress encountered during the grain filling stage of ET rice genotypes increased the MDA content in both the genotypes with ' $N 22$ ' having much lower MDA content than 'IR8' at both anthesis and dough stage of grain filling. This indicates that ' $\mathrm{N} 22$ ' is less susceptible to lipid peroxidation compared to 'IR8'.

Proline (Pro) content was much higher in 'N22' both during ET and NT than 'IR8'. During ET, a much lower Pro content was estimated in 'IR8' (5.5 fold) than 'N22'. We 
found that the Pro content was highest at ET in 'N22' whereas, in 'IR8' it did not vary significantly with date of transplanting ( $\mathrm{p}<$ 0.01 level) (Fig. 2b). Pro is accumulated as osmoprotectant of cellular structure in response to osmotic stress but may also be strongly correlated with the capacity of plants to sense heat stress (Gosavi et al., 2014). The role of Pro accumulation towards greater heat tolerance reported in maize and rice by Kumar et al., (2012) and in cotton by Sekmen et al., (2014) also supports our study.

Fig.1 Changes in the activities of (a) Superoxide dismutase, (b) Catalase, (c) Ascorbate peroxidase, (d) Glutathione reductase and (e) $\mathrm{H}_{2} \mathrm{O}_{2}$ content, (f) Ascorbate content, in rice genotypes at anthesis and dough stage under normal and early transplanting. Genotypes indicated by the same letters, do not differ statistically. Data in the diagram represents mean \pm standard deviation
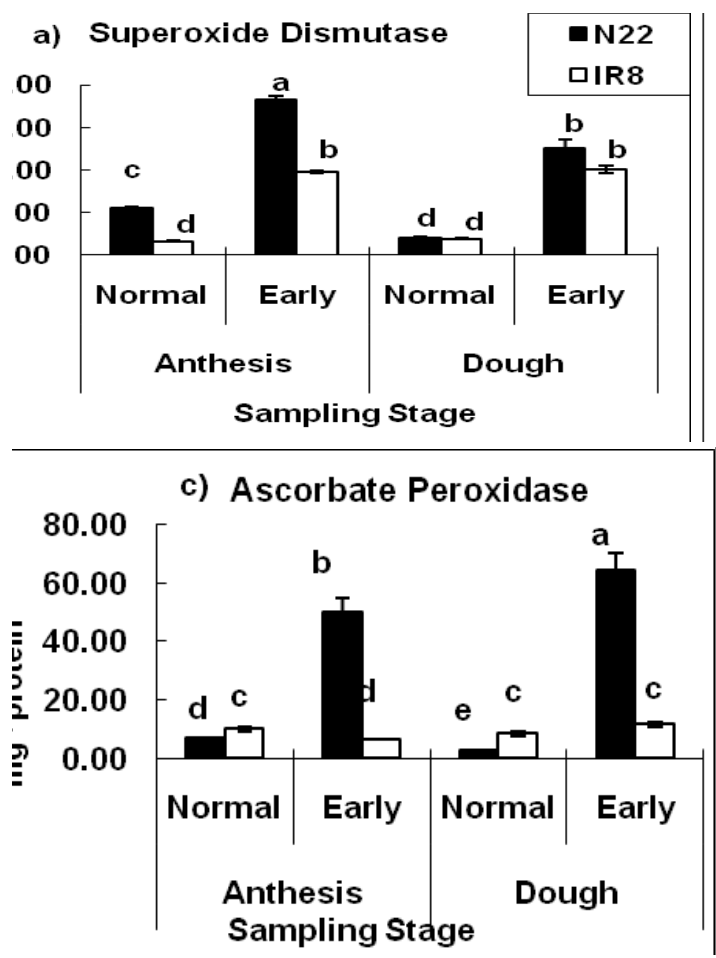

e) Hydrogen Peroxide

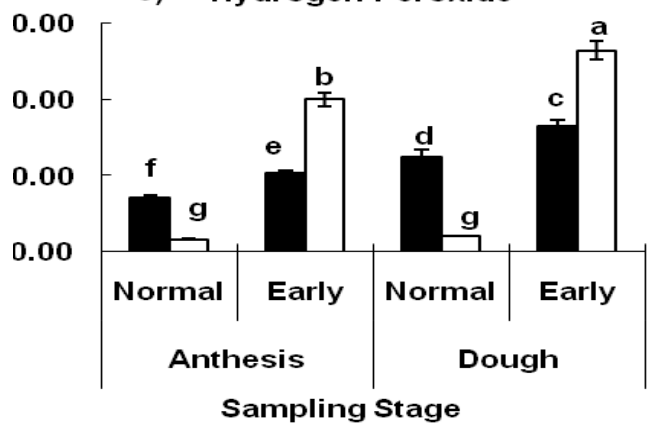

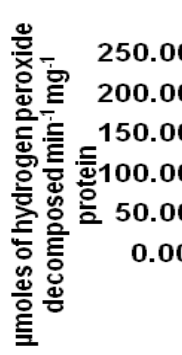

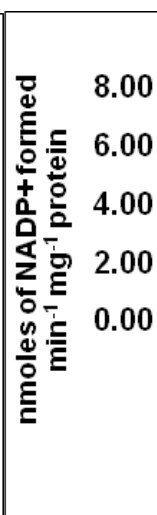

b)

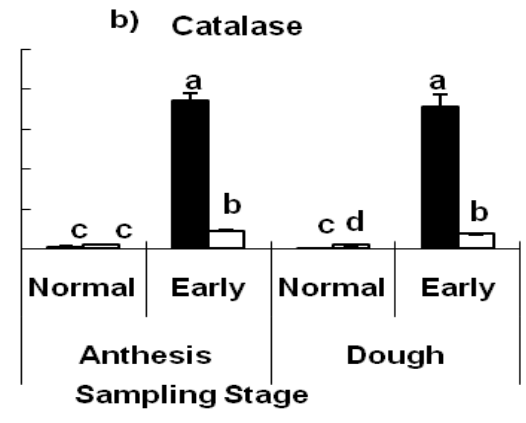

d) Glutathione Reductase
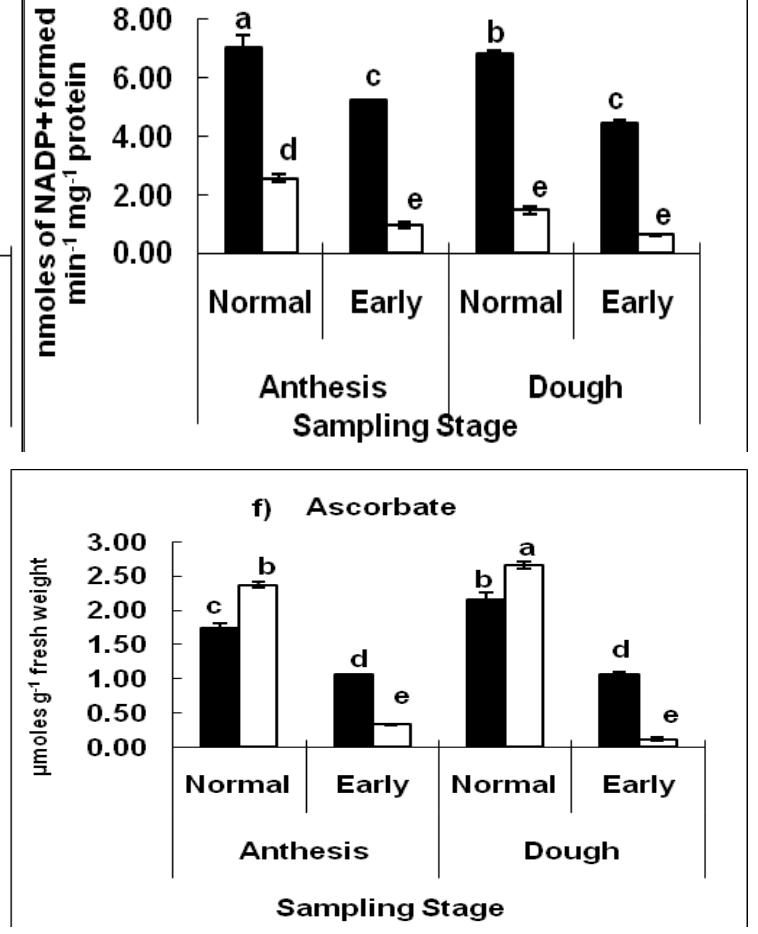
Fig.2 Changes in the (a) Malondialdehyde, (b) Proline, and (c) Total chlorophyll in rice genotypes at anthesis and dough stage under normal and early transplanting. Genotypes indicated by the same letters, do not differ statistically. Data in the diagram represents mean \pm standard deviation

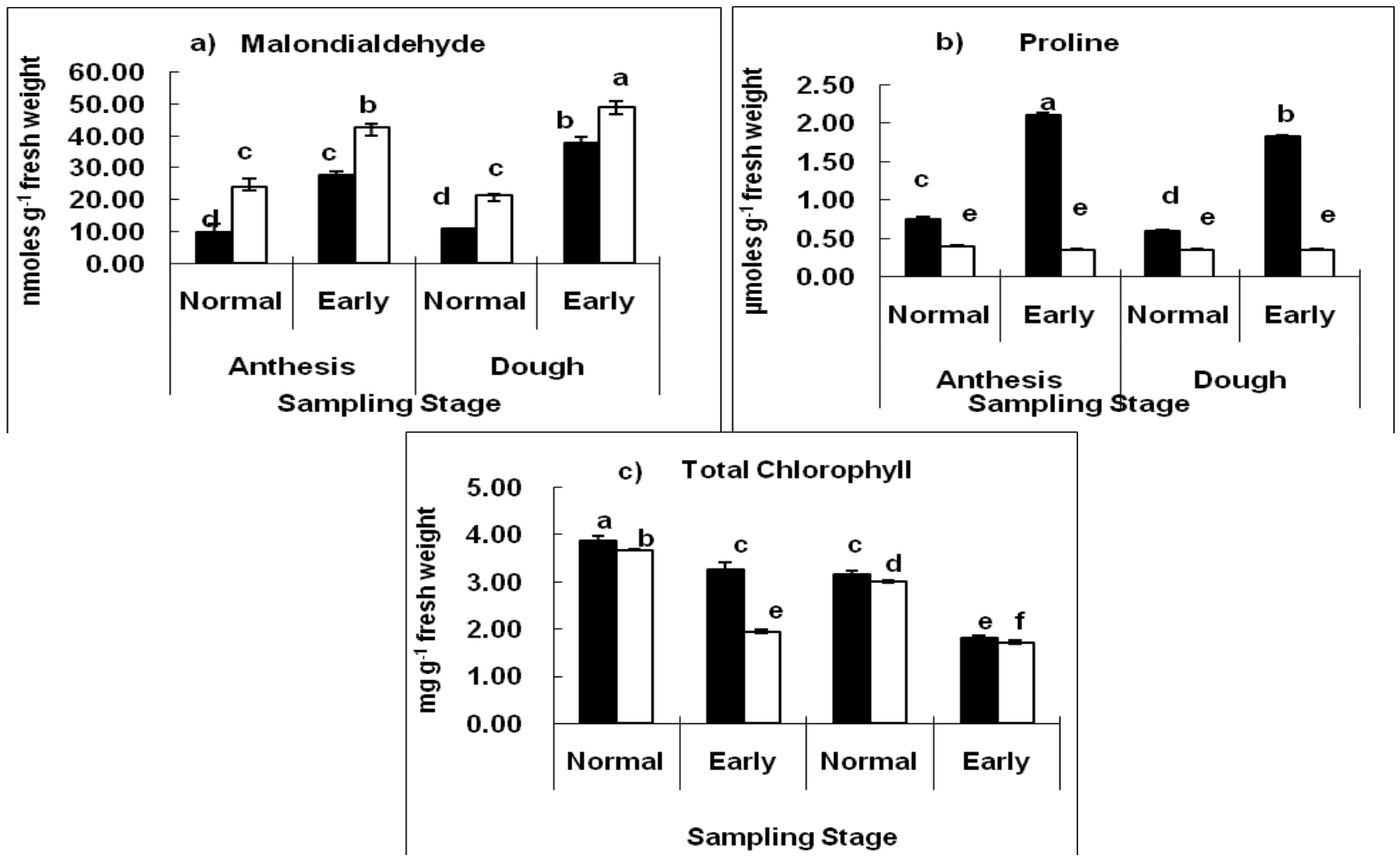

Chlorophyll content in plants is an important trait to assess photosynthesis efficiency under stress conditions. Chlorophyll synthesis is sensitive to heat stress and plants exposed to chill or heat stress have impaired chlorophyll biosynthesis due to downregulation of gene expression and protein abundance of several enzymes involved in tetrapyrrole metabolism (Mohanty et al., 2006). Total chlorophyll content decreased during ET in both the genotypes. A higher reduction $(15.13 \%)$ was found in 'IR8' compared to 'N22', indicating its role in the amelioration of heat stress ( $\mathrm{p}<$ 0.01 level) (Fig. 2c). Reynolds et al., (1994) gave physiological evidence indicating that loss of chlorophyll during grain filling was associated with reduced yield in wheat. Both chlorophyll a and chlorophyll b content were significantly higher in 'N22' compared to 'IR8', during both NT and ET.
Our study revealed that high temperature tolerant genotype ' $\mathrm{N} 22$ ' showed increase in SOD, APX and CAT (ROS scavenging enzymes) under ET and also maintained a greater activity of GR and POX, though the total activity of POX was very low as compared to other antioxidant enzymes. 'N22', the heat tolerant genotype, had lower $\mathrm{H}_{2} \mathrm{O}_{2}$ (a potent oxidant), MDA (lipid peroxidation product) and higher ascorbate (potent antioxidant) and Pro content (osmoprotectant and potent antioxidant) during ET than the temperature sensitive genotype 'IR8'.

Higher activities of SOD and CAT in the scavenging of $\mathrm{H}_{2} \mathrm{O}_{2}$ in both ' $\mathrm{N} 22$ ' and 'IR8' are indicated, suggesting that a major amount of $\mathrm{H}_{2} \mathrm{O}_{2}$ was being scavenged by the CAT route. It may be surmised that the temperature 
tolerance in rice is associated with the timely and co- ordinated response of the antioxidative machinery which includes upregulation of antioxidants and activation of antioxidant enzymes.

\section{List of Abbreviations}

APX: Ascorbate peroxidase; Asc: Ascorbic acid; CAT: Catalase; Chl: Chlorophyll; ET: Early transplanting; GR: Glutathione reductase; $\mathrm{H}_{2} \mathrm{O}_{2}$ : Hydrogen peroxide; MDA: Malondialdehyde; NT: Normal transplanting; ${ }^{1} \mathrm{O}_{2}$ : Singlet oxygen; $\mathrm{O}_{2}{ }^{--}$: Superoxide; $\mathrm{OH}^{*}$ : Hydroxyl radical; POX: Peroxidase; Pro: Proline; ROS: Reactive oxygen species; SOD: Superoxide dismutase; TCA: Trichloroacetic acid

\section{References}

Allakhverdiev, S.I., V. D. Kreslavski, V. V. Klimov, D. A. Los, R. Carpentier, and Mohanty, P 2008. Heat stress: an overview of molecular responses in photosynthesis. Photosynthesis Res. 98: 541-550.

Anderson, J. M., and Boardman, N. K. 1964. Studies on greening of dark-grown bean plants. Aust J Biol Sci. 17: 93-101.

Awasthi, R., N. Kaushal, V. Vadez, N.C. Turner, J. Berger, K. H. M. Siddique, and Nayyar, H. 2014. Individual and combined effects of transient drought and heat stress on carbon assimilation and seed filling in chickpea. Functional Plant Biol. 41: 1148-1167.

Bates, L., R. P. Waldren, and Teare, I. D. 1973. Rapid determination of free proline for water-stress studies. Plant and Soil. 39: 205-207.

Chance, B, and Maehly A. C. 1955. Effects of saline stress and calcium on lipid composition in bean roots. Phytochem. 32: 1131-1136.

Choudhury, F. K., R.M. Rivero, E. Blumwald, and Mittler, R. 2017. Reactive oxygen species, abiotic stress and stress combination. The Plant Journal. 90: 856-867.

Das, A., M. Eldakak, B. Paudel, D. Kim, H. Hemmati, C. Basu, and Rohila, J. S. 2016. Leaf proteome analysis reveals prospective drought and heat stress response mechanisms in soybean. BioMed Res Intl. 1-23.

Esterbauer, H., and Grill, D. 1978. Seasonal variation of glutathione and glutathione reductase in needless of Picea abies. Plant Physiol. 61: 119-121.

Foyer, C.H., and Noctor, G. 2005. Redox homeostasis and antioxidant signaling: a metabolic interface between stress perception and physiological responses. Plant Cell. 17: 1866-1875.

Geisler, M., L. A. Kleczkowski, and Karpinski, S. A. 2006. Universal algorithm for genome-wide in silico identification of biologically significant gene promoter putative cisregulatory-elements: identification of new elements for reactive oxygen species and sucrose signaling in Arabidopsis. Plant J. 45: 384-398.

Gill, S. S., and Tuteja, N. 2010. Reactive oxygen species and antioxidant machinery in abiotic stress tolerance in crop plants. Plant Physiol Biochem. 48: 909-930.

Gosavi, G. U., A. S. Jadhav, A. A. Kale, S.R. Gadakh, B.D. Pawar, and Chimote, V. P. 2014. Effect of heat stress on proline, chlorophyll content, heat shock proteins and antioxidant enzyme activity in sorghum (Sorghum bicolor) at seedlings stage. Indian J Biotechnol. 13: 356-363.

Gourdji, S. M., A.M. Sibley, and Lobell, D. B. 2013. Global crop exposure to critical high temperatures in the reproductive period: historical trends and future predictions. Environ Res Lett. 8: article id. 024041. 
Gur, A., U. Demirel, M. Ozden, A. Kahraman, and Copur, O. 2010. Diurnal gradual heat stress affects antioxidant enzymes, proline accumulation and some physiological components in cotton (Gossypium hirsutum L.). Afri J Biotechnol. 9: 1008-1015.

Hasanuzzaman, M., K. Nahar, M.M. Alam, R. Roychowdhury, and Fujita, M. 2013. Physiological, biochemical, and molecular mechanisms of heat stress tolerance in plants. Intl J Mol Sci. 14: 9643-9684.

Intergovernmental Panel on Climate Change IPCC Working Group I Contribution to the IPCC Fifth Assessment Report on Climate Change 2013: The Physical Science Basis, Summary for Policymakers.

www.climatechange2013.org/images/re port/WG1AR5_SPM_FINAL.pdf

Karuppanapandian, T., J.C. Moon, C. Kim, K. Manoharan, and Kim, W. 2011. Reactive oxygen species in plants: Their generation, signal transduction, and scavenging mechanisms. Aust J Crop Sci. 5: 709-725.

Kumar, S., D. Gupta, and Nayyar, H. 2012. Comparative response of maize and rice genotypes to heat stress: status of oxidative stress and antioxidants. Acta Physiol Planta. 34: 75-86.

Law, M. Y., S.A. Charles, and Halliwell, B. 1983. Glutathione-ascorbic acid in spinach (Spinaceaoleracea) chloroplast. J Biochem. 210: 899-903.

Li, X. Z., M. Z. Liang, G.Q. Zhou, and Chen, L. B. 2002. Effect of environment condition on pollen vigor and seed set during flowering time of rice. Acta Agro Sin. 28: 417-420.

Lowry, O. H., N.J. Rosebrough, A.L. Farr, and Randall, R. J. 1951. Protein measurement with folin-phenol reagent. J Biol Chem. 193: 265-275.

Marklund, S., and Marklund, G. 1974.
Involvement of superoxide anion radical in the autoxidation of pyragallol and a convenient assay for superoxide dismutase. Eur J Biochem. 47: 169-174.

Mohanty, S., B. Grimm, and Tripathy, B.C. 2006. Light and dark modulation of chlorophyll biosynthetic genes in response to temperature. Planta. 224: 692-699.

Nakano, Y., and Asada, K. 1987. Purification of ascorbate peroxidases in spinach chloroplasts: its inactivation in ascorbate depleted medium and reactivation by monodehydro-ascorbate radical. Plant Cell Physiol. 28: 131-140.

Ohkhawa, H., N. Ohishi, and Yogi, K. 1979. Assay for lipid peroxidation in animal tissue by thiobarbituric acid reaction. Analyt Biochem. 95: 351-358.

Osakabe, Y., S. Kajita, and Osakabe, K. 2011. Genetic engineering of woody plants: current and future targets in a stressful environment. Physiol Planta. 142: 105117.

Quan, L. J., B. Zhang, W.W. Shi, and Li, H.Y. 2008. Hydrogen peroxide in plants: a versatile molecule of the reactive oxygen species network. $\mathrm{J}$ Integr Plant Biol. 50: 2-18.

Redondo-Gómez, 2013. Abiotic and Biotic Stress Tolerance in Plants. In: Rout GR, Das AB, eds. Molecular Stress Physiology of Plants. India: Springer India, 1-20.

Reynolds, M. P., M. Balota, M.I.B. Delgado, I. Amani, and Fischer, R. A. 1994. Physiological and morphological traits associated with spring wheat yield under hot, irrigated conditions. Aust J Plant Physiol. 21: 717-730.

Sekmen, A.H., R. Ozgur, B. Uzilday, and Turkan, I. 2014. Reactive oxygen species scavenging capacities of cotton (Gossypium hirsutum) cultivars under combined drought and heat induced oxidative stress. Environ Exp Bot. 99: 
141-149.

Shah, F., J. Huang, K. Cui, L. Nie, T. Shah, C. Chen, and Wang, K. 2011. Impact of high-temperature stress on rice plant and its traits related to tolerance. J Agric Sci. 149: 545-556.

Shannon, L. M., E. Kay, and Lew, J. Y. 1966. Peroxidase isozymes from horse radish roots I. Isolation and physical properties. J Biol Chem. 241: 21662172.

Sharma, P., and Dubey, R. S. 2005. Modulation of nitrate reductase activity in rice seedlings under aluminium toxicity and water stress: role of osmolytes as enzyme protectant. J Plant Physiol. 162: 854-864.

Siddique, K. H. M., S.P. Loss, K.L. Regan, and Jettner, R. L. 1999. Adaptation and seed yield of cool season grain legumes in Mediterranean environments of south-western Australia. Aust J Agric Res. 50: 375-387.

Silva, E. N., S. L. Ferreira-Silva, Ad V. Fontenele, R. V. Ribeiro, R. A. Viégas, and Silveira, J. A. G. 2010. Photosynthetic changes and protective mechanisms against oxidative damage subjected to isolated and combined drought and heat stresses in Jatropha curcas plants. J Plant Physiol. 167: 1157-1164.

Sinha, A. K. 1971. Colorimetric assay of catalase. Anal Biochem. 47: 389-394.

Suriyasak, C., K. Harano, K. Tanamachi, K. Matsuo, A. Tamada, I. M. Iwaya, Ishibashi, Y. 2017. Reactive oxygen species induced by heat stress during grain filling of rice (Oryza sativa L.) are involved in occurrence of grain chalkiness. J Plant Physiol. http://dx.doi.org/10.1016/j.jplph.2017.0 5.015

Tao, L. X., H. J.Tan, W. Wang, L. Y. Cao, and Cheng, S. H. 2007. Effects of high temperature stress on super hybrid rice Guodao 6 during flowering and filling phases. Chin J Rice Sci. 21: 518-524.

Tricker, P. J., H.A. El, J. Schmidt, and Fleury, D. 2018. The physiological and genetic basis of combined drought and heat tolerance in wheat. Published by Oxford University Press on behalf of the Society for Experimental Biology. doi/10.1093/jxb/ery081/4942073

Wahid, A., S. Gelani, M. Ashraf, and Foolad, M. 2007. Heat tolerance in plants: An overview. Environ and Exp Bot. 61: 199-223.

Wang, Y. C., G.Z. Qu, H.Y. Li, Y.J. Wu, C.Wang, G.F.Liu, and Yang, C. P. 2011. Enhanced salt tolerance of transgenic poplar plants expressing a manganese superoxide dismutase from Tamarix androssowii. Mol Biol Rep. 37: 1119-1124.

Yang, Y., C. Han, Q. Liu, B. Lin, and Wang, J. 2008. Effect of drought and low light on growth and enzymatic antioxidant system of Picea asperata seedlings. Acta Plant Physiol. 30: 433-440.

Zafar, S. A., A. Hameed, A.S. Khan, and Ashraf, M. 2017. Heat shock induced morpho-physiological response in indica rice (Oryza sativa L.) at early seedling stage. Pak J Bot. 49: 453-463.

\section{How to cite this article:}

Sharma, K.P., N. Sharma and Kaur, R. 2019. Variation in Antioxidant Responses in Rice (Oryza sativa L.) Genotypes Differing in Sensitivity to Heat Stress. Int.J.Curr.Microbiol.App.Sci. 8(07): 1518-1529. doi: https://doi.org/10.20546/ijcmas.2019.807.181 